\title{
Prediction of small for gestational age neonates in twin pregnancies by first trimester maternal serum PAPP-A and free $\beta$-hCG
}

\author{
Dilek Beker Şanlı', Kazım Kartkaya², Fezan Şahin Mutlu³ \\ ${ }^{1}$ Department of Biochemistry, Ümraniye Training and Research Hospital, Istanbul, Turkey \\ ${ }^{2}$ Department of Biochemistry, Eskişehir State Hospital, Eskişehir, Turkey \\ ${ }^{3}$ Department of Biostatistics, Faculty of Medicine, Eskişehir Osmangazi University, Eskişehir, Turkey
}

\begin{abstract}
Objective: To determine the association between first trimester serum markers and pregnancy complications such as SGA and preterm delivery in twin pregnancies.

Methods: The study included 86 multiple pregnancies. Total study population divided into three study groups as follows: very preterm pregnancies ( $<32$ weeks), preterm pregnancies ( $\geq 32$ and $<37$ weeks) and term pregnancies ( $\geq 37$ weeks). PAPP-A, free $\beta$-hCG and birth weight percentile differences between study groups were tested for statistical significance.

Results: According to birth weight percentiles, there was statistically significant difference between very preterm-preterm and very preterm-term groups $(\mathrm{p}<0.05)$. PAPP-A and free $\beta$-hCG medians for each group were not significantly different $(p>0.05)$. PAPP-A levels below 5 th percentile were associated with low birth weight percentiles in twin pregnancies $(\mathrm{OR}=0.968,95 \% \mathrm{CI}$ for OR 0.945-0.992, $\mathrm{p}=0.008$ ). However, significant association with free $\beta$-hCG was not found regarding SGA.

Conclusion: First trimester maternal serum PAPP-A can be used to predict pregnancy complications like SGA in twin pregnancies.
\end{abstract}

Keywords: Preterm, twin pregnancies, SGA, PAPP-A, free $\beta$ hCG.

\section{Introduction}

The incidence of twin pregnancy is increasing secondary to delayed childbearing and increased use of assisted reproductive techniques. ${ }^{[1]}$ Perinatal complication risk is
Özet: Ikiz gebeliklerde ilk trimester maternal serum PAPP-A ve serbest $\beta$-hCG ile SGA ilișkisi

Amaç: İkiz gebeliklerde preterm doğum ve SGA gibi komplikasyonlar ile birinci trimester serum belirteçleri arasındaki ilişkinin belirlenmesi.

Yöntem: Bu çalışmada 86 ikiz gebelik yer almıştır. Tüm çalışma popülasyonu üç alt gruba ayrılmıştır; ileri derece preterm gebelikler ( $<32 \mathrm{hafta}$ ), preterm gebelikler ( $232 \mathrm{ve}<37 \mathrm{hafta}$ ) ve term gebelikler ( $\geq 37$ hafta). Çalışma grupları arasında PAPP-A, serbest $\beta$-hCG ve doğum kilosu persentili farklılıkları istatistiksel anlamlılık yönünden test edilmiştir.

Bulgular: Doğum kilosu persentillerine göre ileri derece pretermpreterm ve ileri derece preterm-term grupları arasında istatistiksel olarak anlamlı fark bulunmuştur $(\mathrm{p}<0.05)$. Her bir grup için PAPP-A ve serbest $\beta$-hCG medyanları arasında istatistiksel olarak anlamlı fark bulunmamıştır ( $\mathrm{p}>0.05)$. Beşinci persentilin altındaki PAPP-A düzeyleri ikiz gebeliklerde düşük doğum kilosu persentilleri ile ilişkili bulunmuştur (OR=0.968, \%95 CI 0.945-0.992, p=0.008). Fakat SGA bakımından serbest $\beta$-hCG ile anlamlı bir ilişki bulunamamıştır.

Sonuç: İkiz gebeliklerde birinci trimester maternal serum PAPPA düzeyleri SGA gibi gebelik komplikasyonlarının önceden belirlenmesinde kullanilabilir.

Anahtar sözcükler: Preterm, ikiz gebelik, SGA, PAPP-A, serbest $\beta-\mathrm{hCG}$.

appreciably increased in multifetal gestations compared with singletons. ${ }^{[2]}$ Maternal levels of pregnancy associated plasma protein A (PAPP-A) and free beta-human chorionic gonadotropin (free $\beta$-hCG) measured in first
Correspondence: Dilek Beker Şanlı, MD. Ümraniye Eğitim ve Araştırma Hastanesi, Biyokimya Laboratuvarı, İstanbul, Turkey.

e-mail: dilekbeker@yahoo.com

Received: April 15, 2014; Accepted: July 9, 2014
Bu yazının çevrimiçi İngilizce sürümü: www.perinataljournal.com/20140223009 doi:10.2399/prn.14.0223009 Karekod (Quick Response) Code: 
trimester screening have been shown to be associated with development of pregnancy complications such as fetal loss, small for gestational age neonate (SGA), preterm birth or preeclampsia. ${ }^{[3]}$

Preterm delivery is the most important cause of neonatal mortality and morbidity. Respiratory distress syndrome (RDS) and low birth weight $(<2500 \mathrm{~g})$ are very common in infants born before 37 weeks of gestation. Very low birth weight $(<1500 \mathrm{~g})$ is also observed in some preterm infants. According to data of National Center for Health Statistics in U.S., 7.2\% of all livebirths were low birth weight and $1.3 \%$ of all live-births were very low birth weight. ${ }^{[4]}$

Similar to second- trimester serum markers, first trimester free $\beta$-hCG and PAPP-A levels are about twice as high in twins compared with singleton pregnancies. In studies of normal twin pregnancies, average first- trimester free $\beta$-hCG levels were 1.86 multiple of the median (MoM) and PAPP-A levels were 2.10 MoM. ${ }^{[5]}$ Many studies in literature suggest that the concentrations of first trimester serum markers were lower in pregnancy complications such as premature delivery, SGA, and preeclampsia. ${ }^{[6-8]}$

The adverse outcomes resulting from premature delivery and SGA impose a considerable burden on healthcare resources. ${ }^{[9]}$ Therefore, the ability to predict factors which target patients, at higher risk of developing an adverse pregnancy outcome, early in pregnancy would be helpful in the planning of prenatal care. ${ }^{[10]}$

In this study, our purpose was to determine the relationship between first trimester serum markers and pregnancy complications such as SGA and preterm delivery in twin pregnancies.

\section{Methods}

In our study we retrospectively evaluated the data of 86 multiple pregnancies who admitted to the Biochemistry Laboratory of Eskişehir State Hospital to have a first trimester screening test between 2010 and 2012. We determined serum levels of free $\beta$-hCG and PAPP-A by IMMULITE 2000 device (Diagnostic Product Corporation, Los Angeles, CA, USA) of BIO-DPC company which runs with chemiluminescence method. Gestational ages of pregnants were between 11 and 13 weeks $(11 \mathrm{w}+0 \mathrm{~d}$ and $13 \mathrm{w}+6 \mathrm{~d})$. Total study population was divided into 3 study groups as follows: very preterm pregnancies (<32 weeks) which includes 14 cases, preterm pregnancies ( $\geq 32$ and $<37$ weeks) which includes 54 cases, and term pregnancies ( $\geq 37$ weeks) which includes 18 cases.

Birth weight percentiles of twins were evaluated according to Fenton TR generated from Babson and Benda's growth chart by updating with recent data and a new format. ${ }^{[11]}$ PAPP-A, free $\beta$-hCG and birth weight percentile differences between study groups were tested for statistical significance. This study was approved by Ethical Committee of Eskişehir State Hospital.

SPSS IBM 20.0 software (SPSS Inc., Chicago, IL, USA) was used for statistical analysis. Since birth weight percentile, PAPP-A, and free $\beta$-hCG parameters not normally distributed, Kruskal-Wallis one-way analysis of variance by ranks was used. Median (quartiles) values used as defining statistics. In order to assess the relationship between PAPP-A, free $\beta$-hCG and SGA, binary logistic regression analysis was used. A p value less than $0.05(\mathrm{p}<0.05)$ was considered as statistically significant.

\section{Results}

We found statistically significant difference between study groups according to birth weight percentiles $(\mathrm{p}=0.015)$. Table 1 shows the comparison of the three study groups according to birth weight percentiles. There was statistically significant difference between very preterm-preterm group and very preterm-term group ( $\mathrm{p}=0.015, \mathrm{p}=0.035)$. But there was no statistical difference between preterm-term groups $(\mathrm{p}=1.000)$.

We found that PAPP-A medians and free $\beta$-hCG medians for each group was not significantly different $(\mathrm{p}=0.375, \mathrm{p}=0.772)$. PAPP-A and free $\beta$-hCG medians of study groups are presented in Table 2 .

The proportion of SGA events was compared among percentiles of PAPP-A and free $\beta$-hCG by binary logistic regression analysis. PAPP-A levels below 5 th

Table 1. Comparison of birth weight percentiles between study groups.

\begin{tabular}{lcccc} 
Groups & N & $\begin{array}{c}\text { Medians } \\
\text { (Quartiles) }\end{array}$ & Comparisons & p value \\
\hline 1. Very preterm & 14 & $43(35-65)$ & $1-2$ & 0.015 \\
2. Preterm & 54 & $24.5(11.5-40)$ & $1-3$ & 0.035 \\
3. Term & 18 & $24.0(2.5-42.5)$ & $2-3$ & 1.000 \\
\hline
\end{tabular}


percentile were associated with low birth weight percentiles and PAPP-A levels below 5th percentile caused 1.033 times decrease in birth weight percentiles. Low first trimester PAPP-A levels were a strong predictor for SGA in twin gestations (Odds Ratio [OR] $=0.968$, 95\% CI for OR 0.945-0.992, $\mathrm{p}=0.008$ ).

On the other hand, free $\beta$-hCG association with birth weight percentiles did not reach a statistically significant level at different percentile cut-offs. Free $\beta$ hCG levels below 25th percentile caused 1.017 times increase in birth weight percentiles (OR=1.017, 0.975$1.061 \mathrm{p}=0.425$ ) and free $\beta$-hCG levels above 95 th percentile caused 1.028 times decrease in birth weight percentiles $(\mathrm{OR}=0.973,0.942-1.005, \mathrm{p}=0.103)$.

\section{Discussion}

Fetuses at risk for neural tube defects or fetal chromosomal abnormalities as well as women at risk for third trimester obstetric complications can be defined by prenatal screening tests. Maternal serum screening decreases fetal mortality and morbidity by early diagnosis and also helps couples to decide about appropriate delivery strategies. ${ }^{[12]}$ The week of gestation (i.e. 10-14) used for first trimester screening is also the optimal time for early definition of complication risk. ${ }^{[10]}$

Abnormal fetal growth patterns SGA, and large-forgestational age neonate (LGA) are important causes of perinatal morbidity and mortality. By the use of new growth charts that include maternal demographic characteristics, the detection rate for SGA is increased. First trimester PAPP-A and free $\beta$-hCG were studied previously in singleton pregnancies to predict SGA and other third trimester complications, and results of many studies demonstrated a positive correlation of PAPP-A and birth weight. ${ }^{[6-8]}$ However, the association between free $\beta$-hCG and birth weight is not clear. ${ }^{[13]}$ In our study we found statistically significant difference in study groups (very preterm- preterm and very preterm-term) according to birth weight percentiles $(\mathrm{p}<0.05)$.

Table 2. PAPP-A and free $\beta$-hCG results of very preterm, preterm and term groups.

\begin{tabular}{lcccc} 
Groups & $\begin{array}{c}\text { Very preterm } \\
\text { medians } \\
\text { (Quartiles) }\end{array}$ & $\begin{array}{c}\text { Preterm } \\
\text { medians } \\
\text { (Quartiles) }\end{array}$ & $\begin{array}{c}\text { Term } \\
\text { medians } \\
\text { (Quartiles) }\end{array}$ & p value \\
\hline PAPP-A & $5.2(3.7-7.7)$ & $6.7(4.4-9.9)$ & $5.62(4.03-8.7)$ & 0.375 \\
$\beta$-hCG & $53.4(37-84.8)$ & $57.1(43.3-89)$ & $64.6(48.1-85.1)$ & 0.772 \\
\hline
\end{tabular}

Brameld et al. have documented that when PAPP-A is below the 5 th percentile, the risk of preterm birth increased significantly. ${ }^{[14]}$ Laughon demonstrated that free $\beta$-hCG levels below 25 th percentile were associated with very preterm birth before 32 weeks of gestation but not with preterm birth between $\leq 32$ and $<37$ weeks of gestation. PAPP-A was associated with a trend in increased risk of very preterm birth in twin gestations. ${ }^{[15]}$ In our study we found that PAPP- A and free $\beta$-hCG medians were not significantly different for each group (very preterm, preterm, term) in twin pregnancies. When the rates of complications were compared between different PAPP-A levels, severity of growth restriction was found highest at the lowest PAPP-A concentrations. ${ }^{[16]}$ PAPP-A is a trophoblast-specific protein regulating release of free IGFs. Control of the IGF function in early pregnancy may be essential for normal placental perfusion. Many pregnancy complications such as premature delivery, SGA, and preeclampsia may be associated with protease activity of PAPP-A affecting free IGF concentrations and poor placental perfusion. ${ }^{[6]}$

Our findings, like previous reports on singleton pregnancies demonstrate that risk of pregnancy complications such as SGA and premature delivery can be identified in the first trimester in twin gestations and recommended for further testing and closer surveillance throughout the rest of their pregnancy. The objective of this study was to explain the association between first trimester serum markers and the incidence of pregnancy complications by comparing the relative incidence at different percentiles of PAPP-A and free $\beta$-hCG to define the likelihood ratio for SGA and preterm delivery at different marker levels. We found that PAPP-A levels below 5th percentile were associated with 1.033 times decrease in birth weight percentiles. Low first trimester PAPP-A levels were a strong predictor for SGA in twin gestations (OR=0.968, 95\% CI for OR 0.945-0.992, $\mathrm{p}=0.008)$. However, free $\beta$-hCG association with birth weight percentiles at different percentile cut-offs did not reach a statistically significant level.

\section{Conclusion}

Since perinatal mortality risk for twins is much higher than for singleton pregnancies and the great economic burden associated with mortality and morbidity is caused by pregnancy complications, defining the real need for targeting and directing patients in terms of intensive monitoring and interventions is extremely 
important. The results of our study demonstrate that low first trimester maternal serum PAPP-A was a strong predictor for SGA in twin gestations and it may be used as a screening marker for pregnancy complications like SGA in twin pregnancies.

Conflicts of Interest: No conflicts declared.

\section{References}

1. Sperling L, Tabor A. Twin pregnancy: the role of ultrasound in management. Acta Obstet Gynecol Scand 2001;80:287-99.

2. Lee YM, Goldman JC, D'alton ME . Multiple pregnancy. In: Queenan JT, Spong CY, Lockwood CJ (Eds). Management of High-Risk Pregnancy: An Evidence-Based Approach. 5th ed. London: Wiley-Blackwell; 2008: p. 304-15.

3. Kirkegaard I, Henriksen TB, Torring N, Uldbjerg N. PAPP-A and free $\beta-\mathrm{HCG}$ measured prior to 10 weeks is associated with preterm delivery and small-for-gestationalage infants. Prenat Diagn 2011;31:171-5.

4. Burtis CA, Ashwood ER, Bruns DE. Tietz Textbook of Clinical Chemistry and Molecular Diagnostics. Clinical Chemistry of Pregnancy. 4th ed. Philadelphia: Elsevier Saunders; 2006: p. 2166.

5. Malone FD, D'alton ME. Multiple gestation: clinical characteristics and management. In: Creasy RK, Resnik R, Iams JD, Lockwood CL, Moore TR (Eds). Creasy and Resnik's Maternal-Fetal Medicine. 6th ed. Philadelphia: Elsevier Saunders; 2009: p. 453-59.

6. Ranta JK, Raatikainen K, Romppanen J, Pulkki K, Heinonen $\mathrm{S}$. Decreased PAPP-A is associated with preeclampsia, premature delivery and small for gestational age infants but not with placental abruption. Eur J Obstet Gynecol Reprod Biol 2011;157:48-52.

7. Scott F, Coates A, McLennan A. Pregnancy outcome in the setting of extremely low first trimester PAPP-A levels. Aust N Z J Obstet Gynaecol 2009;49:258-62.
8. Peterson SE, Simhan HN. First-trimester pregnancy-associated plasma protein A and subsequent abnormalities of fetal growth. Am J Obstet Gynecol 2008;198:e43-5.

9. Spencer K, Cowans NJ, Molina F, Kagan KO, Nicolaides KH. First-trimester ultrasound and biochemical markers of aneuploidy and the prediction of preterm or early preterm delivery. Ultrasound Obstet Gynecol 2008;31:147-52.

10. Spencer CA, Allen VM, Flowerdew G, Dooley K, Dodds L. Low levels of maternal serum PAPP-A in early pregnancy and the risk of adverse outcomes. Prenat Diagn 2008;28:1029-36.

11. Fenton TR. A new growth chart for preterm babies: Babson and Benda's chart updated with recent data and a new format. BMC Pediatr 2003;3:13.

12. Rose NC, Mennuti MT. Maternal serum screening for neural tube defects and fetal chromosome abnormalities. West J Med 1993;159:312-7.

13. Papastefanou I, Souka AP, Pilalis A, Eleftheriades M, Michalitsi V, Kassanos D. First trimester prediction of smalland large-for-gestation neonates by an integrated model incorporating ultrasound parameters, biochemical indices and maternal characteristics. Acta Obstet Gynecol Scand 2012;91:104-11.

14. Brameld KJ, Dickinson JE, O'Leary P, Bower C, Goldblatt J, Hewitt B, Murch A, Stock R. First trimester predictors of adverse pregnancy outcomes. Aust N Z J Obstet Gynaecol 2008;48:529-35.

15. Laughon SK, Rebarber A, Rolnitzky L, Fink L, Saltzman DH. Decreased first-trimester maternal serum free-beta subunit human chorionic gonadotropin and preterm birth in twin gestations. Am J Perinatol 2009;26:491-4.

16. Cowans NJ, Spencer K. First-trimester ADAM12 and PAPP-A as markers for intrauterine fetal growth restriction through their roles in the insulin-like growth factor system. Prenat Diagn 2007;27:264-71. 